\title{
The synthesis, structures, and electrochemistry of 1'-heteroaryl-2,5-dimethylazaferrocenes
}

\author{
Konrad Kowalski ${ }^{\mathrm{a}, \mathrm{b}, *}$, Rainer F. Winter ${ }^{\mathrm{b}, *}$ \\ ${ }^{a}$ Department of Organic Chemistry, Faculty of Chemistry, University of tódź, Narutowicza 68, 90-136 tódź, Poland \\ ${ }^{\mathrm{b}}$ Institut für Anorganische Chemie der Universität Regensburg, Universitätsstraße 31, D-93040 Regensburg, Germany
}

\section{A B S T R A C T}

We report the synthesis of $1^{\prime}$-heteroaryl-2,5-dimethylazaferrocenes (heteroaryl $=2$-bromothiophen-5-yl and 2-bromopyrid-6-yl) via palladium catalysed cross-coupling reactions along with their crystallographically determined structures. The newly synthesized compounds as well as the parent 2,5-dimethylazaferrocene have been investigated by cyclic voltammetry (CV) and were found to exhibit reversible first oxidations followed by an irreversible oxidation at considerably higher potential.

\section{Introduction}

Aryl- and heteroarylferrocenes are useful building blocks in materials chemistry. This is mainly due to $\pi$-conjugation between the aryl or heteroaryl substituents and the chemically stable, electron rich and redox active ferrocene fragment. Understanding and utilizing these interactions is a key issue in the development of new conductive metallopolymers, molecular wires and optoelectronic materials. With this in mind 1,1'-bis(oligothienyl)ferrocene monomers have been synthesized and investigated $[1,2]$. Their electropolymerization yielded redox-active films which are golden-red in the reduced state. Stepwise oxidation of first the ferrocenyl $(\mathrm{Fc})$ and then the oligothienyl fragments leads to the appearance of low energy oligothienyl $\rightarrow \mathrm{Fc}^{+}$charge transfer bands and then to even more intense oligothienyl polaron bands. Such spectroscopic behavior indicates charge delocalization along the conjugated organometallic system. Other applications of aryl substituted ferrocenes in materials chemistry concern the design and synthesis of liquid crystals [3-5]. The attachment of heteroarenes such as pyridine, bipyridine or phenanthroline to the ferrocenyl moiety has the additional benefit of placing metal binding sites in close proximity to the redox active ferrocene center. Repre-

* Addresses: Department of Organic Chemistry, Faculty of Chemistry, University of Łódź, Narutowicza 68, 90-136 Łódź, Poland (K. Kowalski). Institut für Anorganische Chemie der Universität Regensburg, Universitätsstraße 31, D-93040 Regensburg, Germany (R.F. Winter). Tel.: +48 426355755; fax: +48 426786583 (K. Kowalski), tel.: +49 9414485; fax: +49 9414488 (R.F. Winter).

E-mail addresses: kondor15@wp.pl (K. Kowalski), rainer.winter@chemie.uniregensburg.de (R.F. Winter). sentative examples of such complexes and their coordinating and electrochemical properties have been described by Butler [6,7], Beer [8], Houlton [9], Özkar [10], Siemeling [11], Tani [12], Chupakin [13], Imrie [14] and Ma [15].

As part of an on-going program focused on the various aspects of azaferrocene chemistry [16-19], we have recently turned our interest to the synthesis of 2,5-dimethylazaferrocenes of type $\mathbf{1}$ and $\mathbf{2}$ (Fig. 1) having ethenyl or ethynyl substituents in the 1'-position [20-22].

We believe that, by analogy to ferrocenes, conjugated $\pi$-systems containing azaferrocene have a role to play as building blocks in materials chemistry. The presence of the nitrogen atom in azaferrocene containing $\pi$-conjugated systems may offer new properties and opportunities of tuning them, e.g. by protonation or the coordination of additional metal centers which are not as easily accessible for their ferrocene counterparts.

Comparative cyclic voltammetry studies of aryl-capped ethenylazaferrocenes and aryl-capped ethenylferrocenes have indicated that the azaferrocenyl entity acts as a weaker electron donor and stronger electron withdrawing group than the ferrocenyl one [20]. This becomes evident when the oxidation potentials of $p$ methoxystyryl-2,5-dimethylazaferrocene and $p$-methoxystyrylferrocene are compared [20]. In case of ferrocene, $p$-methoxystyryl substitution effects a $60 \mathrm{mV}$ cathodic shift of the $\mathrm{Fc} / \mathrm{Fc}^{+}$couple whereas the analogous shift for azaferrocene is $380 \mathrm{mV}$ [20]. Interestingly, however, introduction of the ethynyl groups to ferrocene and to 2,5-dimethylazaferrocene brings about the same anodic shift of approximately $160 \mathrm{mV}$ [21].

In continuation of our studies in 2,5-dimethylazaferrocene chemistry, we have turned our interest toward the synthesis of 


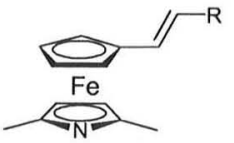

1

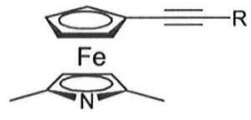

2
Fig. 1. The general structures of 1'-ethenyl (1) and 1'-ethynyl (2) 2,5-dimethylazaferrocenes studied so far.

its 1'-aryl derivatives. In this paper, we report on the synthesis, structure, and on cyclic voltammetry studies of $1^{\prime}$-(2-bromothiophen-5-yl)-2,5-dimethylazaferrocene (3) and 1'-(2-bromopyridin6-yl)-2,5-dimethylazaferrocene (4). We have also reinvestigated the electrochemistry of parent 2,5-dimethylazaferrocene (5). To the best of our knowledge complexes $\mathbf{3}$ and $\mathbf{4}$ are the first examples of $1^{\prime}$-heteroarylazaferrocenes reported to date. Very recently, Swager described the synthesis of 2,5-thiophenyl-substituted $1^{\prime}, 2^{\prime}, 3^{\prime}, 4^{\prime}, 5^{\prime}$-pentamethylazaferrocenes in order to study their electropolymerization and the conductive properties of the resulting metallopolymers [23].

\section{Results and discussion}

\subsection{Synthesis of $\mathbf{3}$ and $\mathbf{4}$}

Various types of palladium catalysed cross-coupling reactions have proved their value in the synthesis of aryl substituted ferrocenes. Representative examples of such reactions are the Suzuki type coupling of iodoferrocene with arylboronic acids $[24,25]$ or of ferrocenylboronic acid with aryl halides [26], and Stille couplings of tributylstannylferrocene with heteroaryl bromides $[15,27]$. Alternative synthetic strategies are based on palladium catalysed cross-coupling reactions of bis(ferrocenyl)mercury with aryl iodides [28] or Negishi couplings of ferrocenylzinc chlorides with aryl bromides [29-31]. Our synthetic strategy (Scheme 1) has been stimulated by the work of Iyoda [32].

The procedure for the synthesis of $\mathbf{3}$ and $\mathbf{4}$ involves lithiation of 2,5-dimethylazaferrocene (5) under previously described conditions [16] followed by addition of $\mathrm{ZnCl}_{2}$. Subsequent transmetallation with catalytical amounts of $\mathrm{PdCl}_{2}\left(\mathrm{PPh}_{3}\right)_{2}$ in THF and addition of the bromoarene gave products 3 and 4 in $46 \%$ and $43 \%$ isolated yields, respectively, after standard workup and crystallization from $n$-hexane. The yields are very satisfactory when considering that under the applied conditions only $54 \%$ of starting 2,5-dimethylazaferrocene are lithiated at the $\mathrm{Cp}$ ring [16] and that the reaction involves a transmetallation step. Both products are air stable solids which gave X-ray quality crystals upon crystallization from $n$-hexane. The above methodology emerges as a new tool in the synthetic chemistry of azaferrocenes and complements previously known ones like lithiathion $[16,17,19]$ and Friedel-Crafts acylation reactions [18]. Additionally, the presence of the reactive bromide in $\mathbf{3}$ and $\mathbf{4}$ opens the way to their further functionalization.

The structures of $\mathbf{3}$ and $\mathbf{4}$ were confirmed by spectroscopic methods and elemental analyses. The ${ }^{1} \mathrm{H}$ NMR spectrum of $\mathbf{3}$ shows two doublets at $6.90 \mathrm{ppm}$ and $6.82 \mathrm{ppm}$ for the thienyl protons, two triplets at $4.43 \mathrm{ppm}$ and $4.30 \mathrm{ppm}$ for the substituted cyclopentadienyl ligand, a singlet at $4.27 \mathrm{ppm}$ for the $\beta$-pyrrolyl protons and a singlet at $2.11 \mathrm{ppm}$ from the two $\alpha$-pyrrolyl methyl groups. The ${ }^{1} \mathrm{H}$ NMR spectrum of $\mathbf{4}$ exhibits a low-field triplet at $7.49 \mathrm{ppm}$ and two doublets at 7.38 and $7.30 \mathrm{ppm}$ that are characteristic of the 2,6-disubstituted pyridine. The two triplets of the cyclopentadienyl protons appear at 4.83 and $4.41 \mathrm{ppm}$ and thus at lower field than in $\mathbf{3}$, which can be rationalized by the stronger electron withdrawing effect of the pyridyl substituent. This points to $\pi$-conjugation between the ferrocenyl and the heteroaryl rings as it is also present in the crystalline state (see below).

\subsection{X-ray diffraction study of compounds 3 and 4}

Compounds $\mathbf{3}$ and $\mathbf{4}$ crystallize in the monoclinic space group $P 2_{1} / n$ or the orthorhombic space group $P 2_{1} 2{ }_{1} 2$, respectively. Data pertaining to the data collection and structure refinement are collected in Table 1 . Table 2 provides a selection of the most important interatomic distances and bond angles. Plots of individual molecules of $\mathbf{3}$ and $\mathbf{4}$ are displayed in Figs. 2 and 3. In both structures, the heteroaryl substituent is nearly coplanar to the attached cyclopentadienyl ring and forms an interplanar angle of 8.6 (3) or $8.9^{\circ}(4)$ with the latter. The iron atom is symmetrically displaced between the different cyclic $\pi$-perimeters with distances of 1.656 (3) or $1.652 \AA$ (4) to the centroid of the substituted cyclopentadienyl ring ( $C \mathrm{p}_{\text {centr }}$ ) and $1.654 \AA$ to the pyrrolyl ring $\left(\mathrm{Pyr}_{\text {centr }}\right)$ in both, 3 and $\mathbf{4}$. The two rings adopt an almost eclipsed conformation in $\mathbf{3}$ and a gauche conformation halfway between staggered and

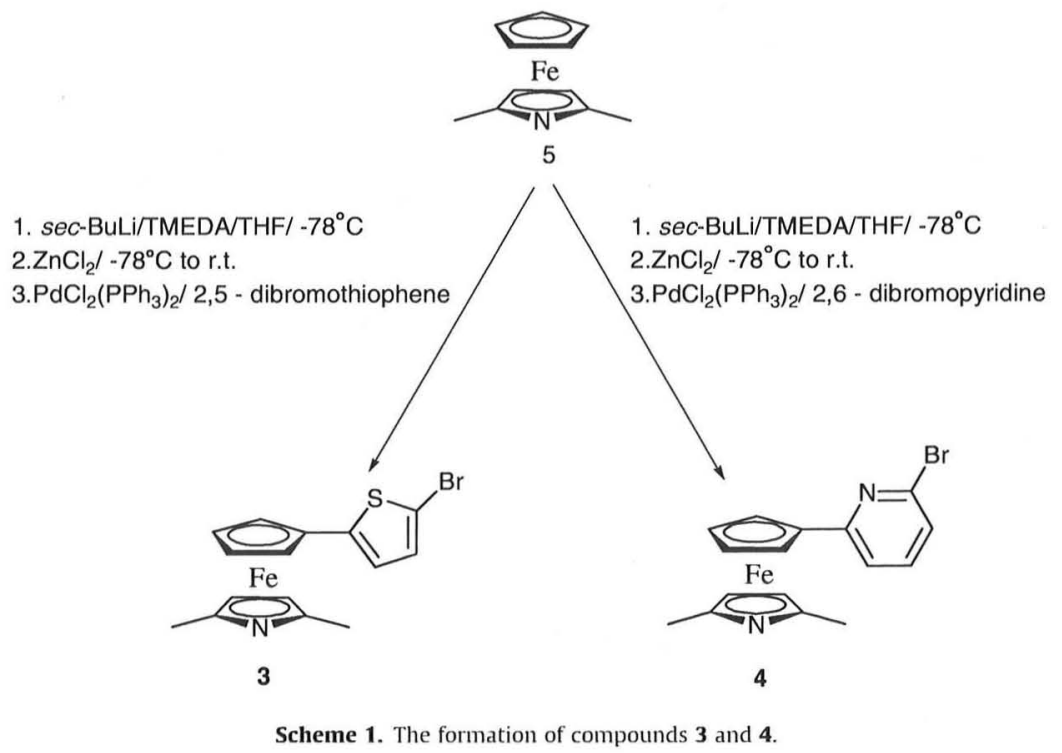


Table 1

Crystal data and structure refinement for $\mathbf{3}$ and $\mathbf{4}$

\begin{tabular}{|c|c|c|}
\hline Compound & 3 & 4 \\
\hline Empirical formula & $\mathrm{C}_{15} \mathrm{H}_{14} \mathrm{BrFeNS}$ & $\mathrm{C}_{16} \mathrm{H}_{15} \mathrm{BrFeN}_{2}$ \\
\hline Formula weight & 376.09 & 371.05 \\
\hline Temperature (K) & $123(1)$ & $123(1)$ \\
\hline Wavelength $(\AA), \mathrm{Cu} \mathrm{K} \alpha$ & 1.54184 & 1.54184 \\
\hline Crystal system, space group & Monoclinic, $P 2_{1} / n$ & Orthorhombic, $P 2_{1} 2_{1} 2$ \\
\hline \multicolumn{3}{|l|}{ Unit cell dimensions } \\
\hline$a(\AA)$ & $12.2042(2)$ & $11.1718(2)$ \\
\hline$b(A)$ & $8.25140(10)$ & $15.8620(3)$ \\
\hline$\beta\left({ }^{\circ}\right)$ & $108.877(2)$ & \\
\hline$c(\AA)$ & $14.7311(3)$ & $8.0941(2)$ \\
\hline Volume $\left(\AA^{3}\right), Z$ & $1403.66(4), 4$ & $1434.33(5), 4$ \\
\hline$D_{\text {calc }}\left(\mathrm{Mg} / \mathrm{m}^{3}\right)$ & 1.780 & 1.718 \\
\hline $\begin{array}{l}\text { Absorption coefficient } \\
\left(\mathrm{mm}^{-1}\right)\end{array}$ & 13.194 & 11.600 \\
\hline$F(000)$ & 752 & 744 \\
\hline Crystal color/morphology & Orange-red plate & Orange-red plate \\
\hline Crystal size (mm) & $0.23 \times 0.20 \times 0.05$ & $0.23 \times 0.11 \times 0.07$ \\
\hline $\begin{array}{l}\theta \text { Range for data collection } \\
\left({ }^{\circ}\right)\end{array}$ & $4.11-62.17$ & $4.84-62.01$ \\
\hline Index ranges & $\begin{array}{l}-13 \leqslant h \leqslant 13,-9 \leqslant k \leqslant 8 \\
-16 \leqslant l \leqslant 16\end{array}$ & $\begin{array}{l}-12 \leqslant h \leqslant 7 \\
-17 \leqslant k \leqslant 18 \\
-8 \leqslant l \leqslant 9\end{array}$ \\
\hline $\begin{array}{l}\text { Reflections collected/unique } \\
{\left[\begin{array}{l}\left.R_{\text {int }}\right]\end{array}\right.}\end{array}$ & $9176 / 2197[0.0381]$ & $3731 / 1889[0.0317]$ \\
\hline $\begin{array}{l}\text { Reflections observed } \\
\qquad[I>2 \sigma(I)]\end{array}$ & 1839 & 1597 \\
\hline Absorption correction & $\begin{array}{l}\text { Semi-empirical from } \\
\text { equivalents }\end{array}$ & $\begin{array}{l}\text { Semi-empirical from } \\
\text { equivalents }\end{array}$ \\
\hline Data/restraints/parameters & $2197 / 0 / 172$ & $1889 / 0 / 183$ \\
\hline Goodness-of-fit on $F^{2}$ & 1.053 & 0.955 \\
\hline Final $R$ indices $[I>2 \sigma(I)]$ & $R_{1}=0.0370, w R_{2}=0.1032$ & $\begin{array}{l}R_{1}=0.0305 \\
w R_{2}=0.0678\end{array}$ \\
\hline$R$ indices (all data) & $R_{1}=0.0437, w R_{2}=0.1086$ & $\begin{array}{l}R_{1}=0.0378 \\
w R_{2}=0.0697\end{array}$ \\
\hline $\begin{array}{l}\text { Largest difference in peak, } \\
\text { hole }\left(\mathrm{e} \cdot \AA^{-3}\right)\end{array}$ & $0.108,-0.487$ & $0.375,-0.405$ \\
\hline
\end{tabular}

Table 2

Selected bond lengths $(\mathcal{A})$ and bond angles $\left({ }^{\circ}\right)$ for compounds $\mathbf{3}$ and $\mathbf{4}$

\begin{tabular}{llll}
\hline $\mathbf{3}$ & & $\mathbf{4}$ & \\
\hline $\mathrm{Br}(1)-\mathrm{C}(15)$ & $1.880(4)$ & $\mathrm{Br}(1)-\mathrm{C}(16)$ & $1.928(5)$ \\
$\mathrm{S}(1)-\mathrm{C}(12)$ & $1.733(4)$ & $\mathrm{N}(2)-\mathrm{C}(12)$ & $1.372(7)$ \\
$\mathrm{S}(1)-\mathrm{C}(15)$ & $1.718(4)$ & $\mathrm{N}(2)-\mathrm{C}(16)$ & $1.310(8)$ \\
$\mathrm{C}(12)-\mathrm{C}(13)$ & $1.374(6)$ & $\mathrm{C}(12)-\mathrm{C}(13)$ & $1.384(7)$ \\
$\mathrm{C}(13)-\mathrm{C}(14)$ & $1.407(7)$ & $\mathrm{C}(13)-\mathrm{C}(14)$ & $1.383(8)$ \\
$\mathrm{C}(14)-\mathrm{C}(15)$ & $1.341(6)$ & $\mathrm{C}(14)-\mathrm{C}(15)$ & $1.375(8)$ \\
$\mathrm{C}(7)-\mathrm{C}(12)$ & $1.460(6)$ & $\mathrm{C}(15)-\mathrm{C}(16)$ & $1.379(7)$ \\
$\mathrm{Fe}(1)-\mathrm{N}(1)$ & $2.031(3)$ & $\mathrm{C}(7)-\mathrm{C}(12)$ & $1.468(7)$ \\
$\mathrm{Fe}(1)-\mathrm{C}(7)$ & $2.063(4)$ & $\mathrm{Fe}(1)-\mathrm{N}(1)$ & $2.035(5)$ \\
$\mathrm{C}(8)-\mathrm{C}(7)-\mathrm{C}(12)$ & $126.8(4)$ & $\mathrm{Fe}(1)-\mathrm{C}(7)$ & $2.048(5)$ \\
$\mathrm{S}(1)-\mathrm{C}(12)-\mathrm{C}(7)$ & $120.6(3)$ & $\mathrm{C}(8)-\mathrm{C}(7)-\mathrm{C}(12)$ & $126.5(4)$ \\
$\mathrm{S}(1)-\mathrm{C}(12)-\mathrm{C}(13)$ & $110.5(3)$ & $\mathrm{N}(2)-\mathrm{C}(12)-\mathrm{C}(13)$ & $121.2(5)$ \\
$\mathrm{C}(7)-\mathrm{C}(12)-\mathrm{C}(13)$ & $128.9(4)$ & $\mathrm{N}(2)-\mathrm{C}(12)-\mathrm{C}(7)$ & $116.3(5)$ \\
$\mathrm{C}(12)-\mathrm{C}(13)-\mathrm{C}(14)$ & $113.2(4)$ & $\mathrm{C}(7)-\mathrm{C}(12)-\mathrm{C}(13)$ & $122.5(5)$ \\
$\mathrm{C}(13)-\mathrm{C}(14)-\mathrm{C}(15)$ & $112.6(4)$ & $\mathrm{C}(12)-\mathrm{C}(13)-\mathrm{C}(14)$ & $119.5(5)$ \\
$\mathrm{Br}(1)-\mathrm{C}(15)-\mathrm{S}(1)$ & $120.1(2)$ & $\mathrm{C}(13)-\mathrm{C}(14)-\mathrm{C}(15)$ & $120.4(5)$ \\
$\mathrm{Br}(1)-\mathrm{C}(15)-\mathrm{C}(14)$ & $127.1(3)$ & $\mathrm{C}(14)-\mathrm{C}(15)-\mathrm{C}(16)$ & $115.0(5)$ \\
$\mathrm{S}(1)-\mathrm{C}(15)-\mathrm{C}(14)$ & $112.7(3)$ & $\mathrm{N}(2)-\mathrm{C}(16)-\mathrm{C}(15)$ & $128.1(5)$ \\
& & $\mathrm{Br}(1)-\mathrm{C}(16)-\mathrm{N}(2)$ & $114.9(4)$ \\
& & $\mathrm{Br}(1)-\mathrm{C}(16)-\mathrm{C}(15)$ & $117.0(4)$ \\
\hline
\end{tabular}

eclipsed in 4; the average $\mathrm{C}(\mathrm{Cp})-\mathrm{Cp}_{\text {centr }}-\mathrm{Pyr}_{\mathrm{centr}}-\mathrm{C} / \mathrm{N}(\mathrm{Pyr})$ angle is $8.4^{\circ}(3)$ or $16.9^{\circ}(4)$. Other structural features within the azaferrocenyl and the heteroaryl rings are unexceptional and warrant no further discussion.

In the solid state, compounds $\mathbf{3}$ and $\mathbf{4}$ exhibit interesting packing motifs. Compound $\mathbf{4}$ forms centrosymmetric dimers that are held together by pairs of $\mathrm{CH} \cdots \mathrm{N}$ interactions with $\mathrm{N} \cdots \mathrm{H}$ distances of 2.524 and $2.631 \AA$ between the pyrrolyl nitrogen atom $\mathrm{N}(1)$ and hydrogen atoms $\mathrm{H}(13)$ and $\mathrm{H}(11)$ on the pyridyl and the cyclopen-

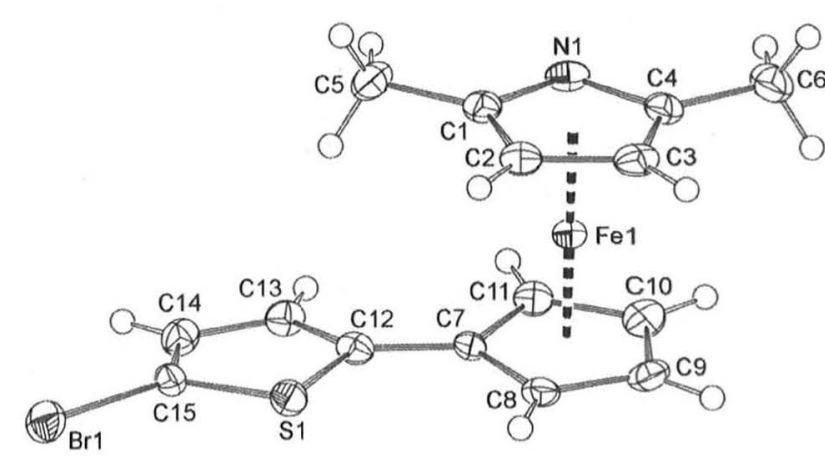

Fig. 2. ORTEP plot of the molecular structure of complex $\mathbf{3}$ in the crystal. Ellipsoids are given at a $50 \%$ probability level.

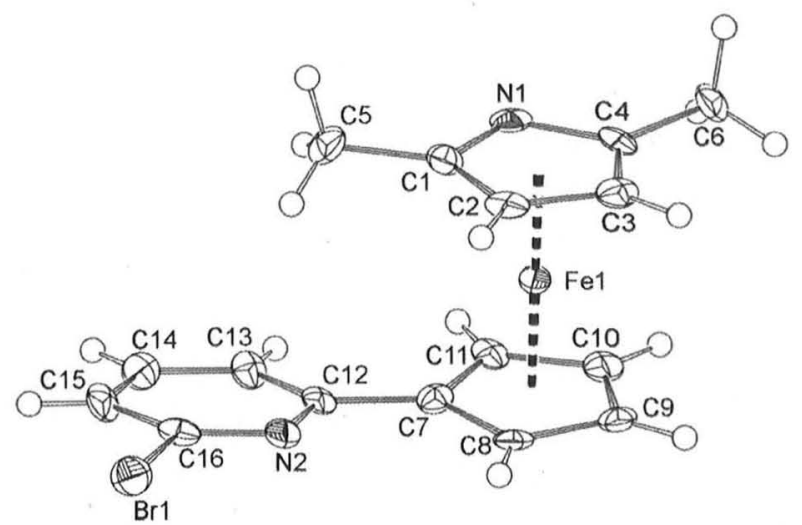

Fig. 3. ORTEP plot of the molecular structure of complex 4 in the crystal. Ellipsoids are given at a $50 \%$ probability level.

tadienyl rings. The stronger $\mathrm{CH} \cdots \mathrm{N}$ interaction to the $\mathrm{CH}$ on the pyridyl ring probably reflects its superior electron accepting properties. These dimers are interlinked to two-dimensional sheets parallel to the ac plane by weaker contacts of $2.735 \AA$ A between $\mathrm{H}(2)$ of the pyrrolyl ring and the pyridyl nitrogen atom N(2) and of $3.022 \AA$ between $\mathrm{Br}(1)$ and cyclopentadienyl proton $\mathrm{H}(9)$. Individual sheets are loosely connected along the $b$ axis by $\mathrm{CH}-\pi$-interactions of $2.89 \AA$ between the pyridyl proton $\mathrm{H}(15)$ and carbon atoms $\mathrm{C}(3)$ and $\mathrm{C}(4)$ of the pyrrolyl ring (Fig. 4). $\mathrm{CH} \cdots \mathrm{N}$ contacts between cyclopentadienyl protons and imine nitrogen atoms of appended nitrogen containing heterocycles have, for example, also been observed in 1-(pyrimidin-4-yl)ferrocene, which also crystallizes as hydrogen bonded dimers $(\mathrm{CH} \cdots \mathrm{N}=2.49 \AA$ ) [33].

In compound 3 individual molecules form infinite one-dimensional zig-zag chains that are again held together by $\mathrm{CH} \ldots \mathrm{N}$ interactions of 2.506 and $2.627 \AA$ between the pyrrolyl nitrogen atom $\mathrm{N}(1)$ and hydrogen atoms $\mathrm{H}(13)$ of the thienyl ring and $\mathrm{H}(11)$ of the $\mathrm{Cp}$ ring of its neighbor. These chains are weakly interconnected by $\mathrm{S} \ldots \mathrm{Br}$ contacts of $3.523(1) \AA$ and $\mathrm{CH}$. . C contacts between $\mathrm{H}(15)$ and $C(9)$ of $2.816 \AA$ in one-dimension and by $\mathrm{S} \cdots \mathrm{H}(8)$ contacts of $2.992 \AA$ in the other (Fig. 5).

\subsection{Cyclic voltammetrical study of $\mathbf{3}, \mathbf{4}$ and $\mathbf{5}$}

The significance of the ferrocenyl moiety in materials science and as a component of molecular devices or sensors largely relies on its powerful electron donating effect, low oxidation potential, fast electron transfer kinetics and the chemical stability of its 


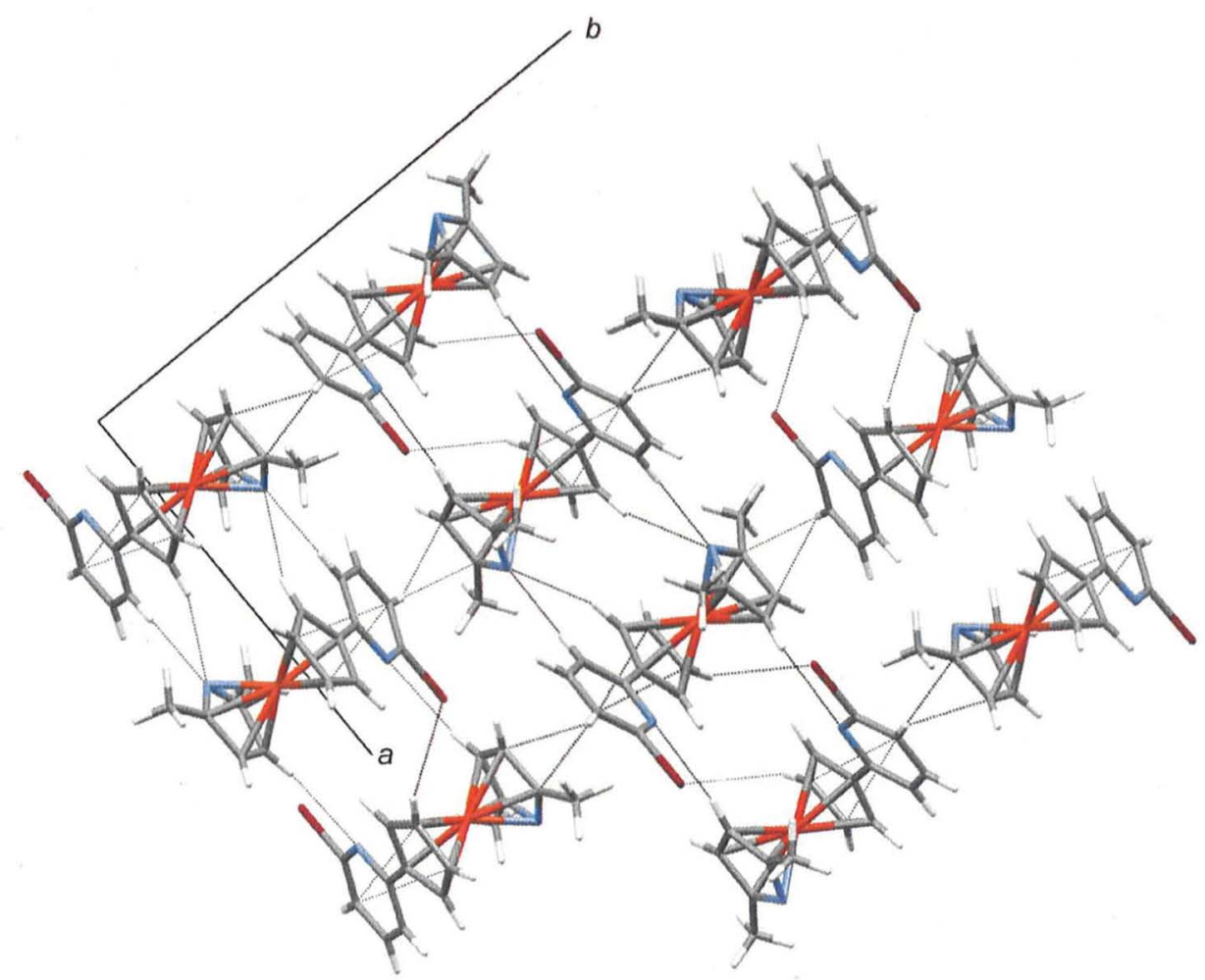

Fig. 4. Packing diagram of complex $\mathbf{4}$ in the solid state; view along the $c$ axis.

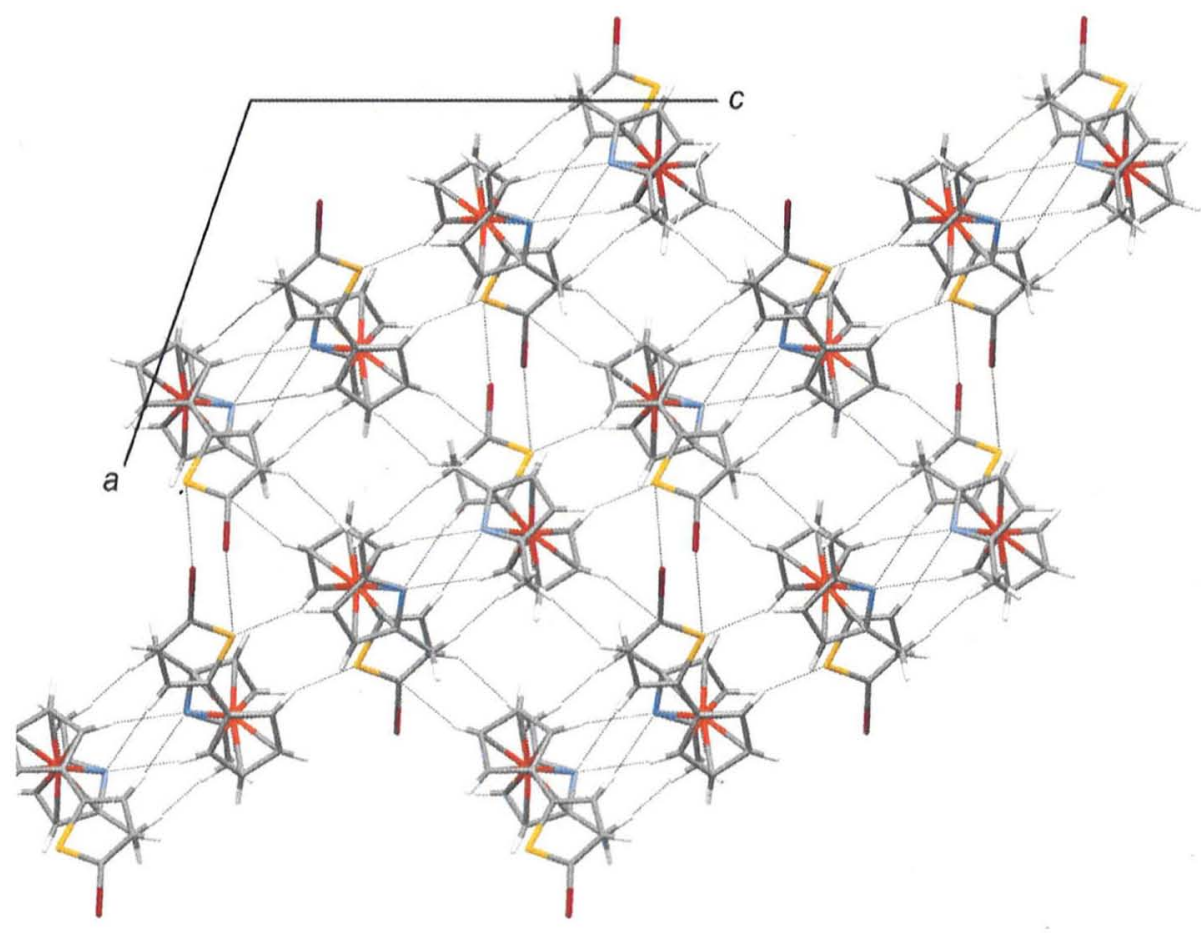

Fig. 5. Packing diagram of complex 3 in the solid state; view along the $b$ axis.

oxidized form. Research into heteroatom substituted ferrocenes has consequently addressed issues such as the influence of heteroatom substitution of $\mathrm{CH}$ groups on the redox potentials and on the chemical stabilities of the associated radical cations. In the group 15 series of ferrocene derivatives there is a general consensus that incremental $\mathrm{CH}$ substitution by $\mathrm{P}$ or $\mathrm{N}$ increases $E_{1 / 2}$ and renders 
Table 3

Voltammetric data for compounds 3-5

\begin{tabular}{|c|c|c|}
\hline Compound & $\begin{array}{l}E_{1 / 2}{ }^{0 /+}[\mathrm{V}]\left[\Delta E_{\mathrm{p}} \text { in } \mathrm{mV} ;\right. \\
E_{\mathrm{p}, \mathrm{f}}-E_{\left.\mathrm{p}, \mathrm{f} / 2^{\mathrm{a}} \text { in } \mathrm{mV}\right]}\end{array}$ & $E_{\mathrm{p}}{ }^{+/ \mathrm{n}+\mathrm{b}}[\mathrm{V}]\left[E_{\mathrm{p}, \mathrm{f}}-E_{\mathrm{p}, \mathrm{f} / \mathbf{2}^{\mathrm{a}}}\right.$ in $\left.\mathrm{mV}\right]$ \\
\hline 5 & $0.17[68 ; 63]$ & $1.02[98]$ \\
\hline 3 & $0.215[59,57]$ & $0.88[52]$ \\
\hline 4 & $0.265[59 ; 57]$ & $1.03[86]$ \\
\hline
\end{tabular}

the associated cations more susceptible to nucleophilic attack or deprotonation [34-37]. Quantum mechanical studies on aza- and phosphaferrocenes disclosed that sequential heteroatom incorporation induces some charge shift from the iron and the remaining cyclopentadienyl ring to the $\pi$-coordinated heterocycle and thus increases the potential of the still iron based oxidation [38].

With this in mind, we investigated compounds $\mathbf{3}$ and $\mathbf{4}$ by cyclic and square wave voltammetry. We also reinvestigated the electrochemical behavior of parent 2,5-dimethylazaferrocene (5), which has been reported to require sweep rates of $1 \mathrm{~V} / \mathrm{s}$ in order to suppress chemical processes following oxidation [34]. In our hands all investigated compounds gave close to ideal diffusion controlled one-electron waves even at sweep rates as low as $25 \mathrm{mV} / \mathrm{s}$ with peak current ratios $i_{\text {p.cathodic }} / i_{\text {p.anodic }}$ of $\geqslant 0.95$ and peak-potential separations $\Delta E_{\mathrm{p}}$ and forward-wave half-widths $E_{\mathrm{p}, \mathrm{f}}-E_{\mathrm{p}, \mathrm{f} / 2}$ that are very similar or identical to those of the internal decamethylferrocene or ferrocene standards. Pertinent data are collected in Table 3 and typical voltammograms are displayed in Figs. 6-8. Similar to phosphaferrocenes, there is an additional irreversible oxidation at distinctly higher potentials which may be due to electron abstraction from the heteroatom lone-pair. Scanning through this wave causes electrode fauling of both, platinum and glassy carbon. For 3 the second oxidation constitutes a multi electron process and likely involves the appended thienyl ring, its oxidation possibly overlapping with the second azaferrocene based anodic process. In the case of $\mathbf{3}$ and $\mathbf{4}$ a cathodic return peak associated with the second couple appears upon cooling to $195 \mathrm{~K}$. In view of the large $\Delta E_{\mathrm{p}}$ and the disappearance of the cathodic return peak associated with the first oxidation wave in the case of $\mathbf{3}$ its significance

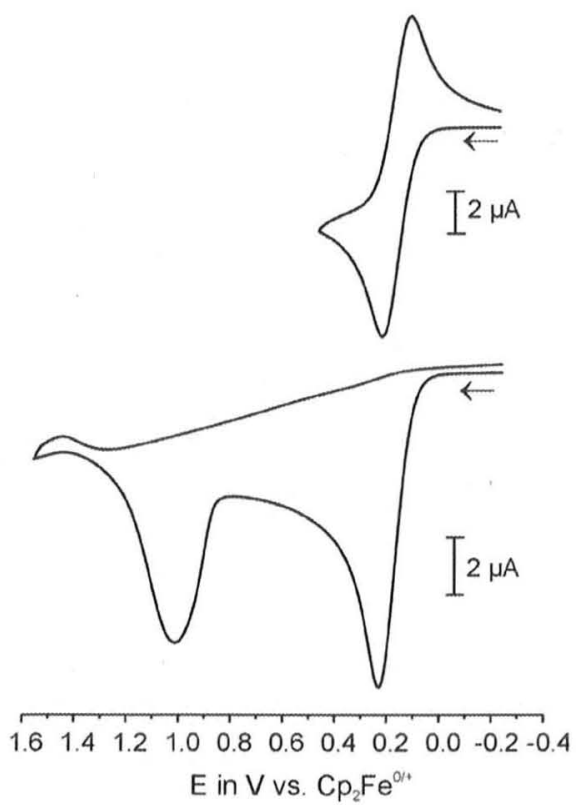

Fig. 6. Voltammograms of 5 in $\mathrm{CH}_{2} \mathrm{Cl}_{2} / \mathrm{NBu}_{4} \mathrm{PF}_{6}(0.1 \mathrm{M}, \mathrm{RT}$ ) at $v=0.1 \mathrm{~V} / \mathrm{s}$ (lower curve) and at $v=0.05 \mathrm{~V} / \mathrm{s}$ (upper curve).

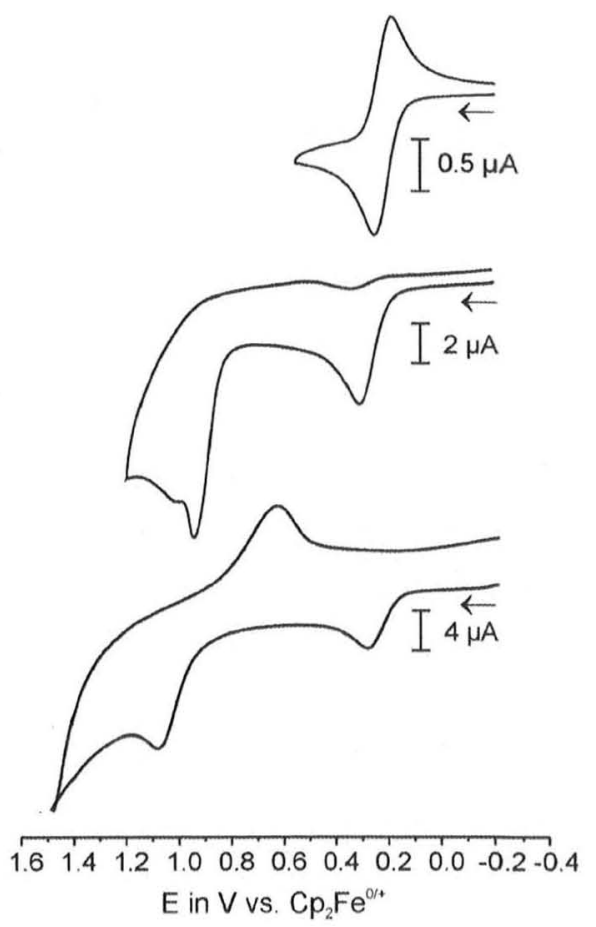

Fig. 7. Voltammograms of 3 in $\mathrm{CH}_{2} \mathrm{Cl}_{2} / \mathrm{NBu}_{4} \mathrm{PF}_{6}(0.1 \mathrm{M})$ at $v=1.0 \mathrm{~V} / \mathrm{s}$ at $195 \mathrm{~K}$ (lower curve), at $v=0.1 \mathrm{~V} / \mathrm{s}$ at RT (middle) and at $v=0.05 \mathrm{~V} / \mathrm{s}$ at RT (top).
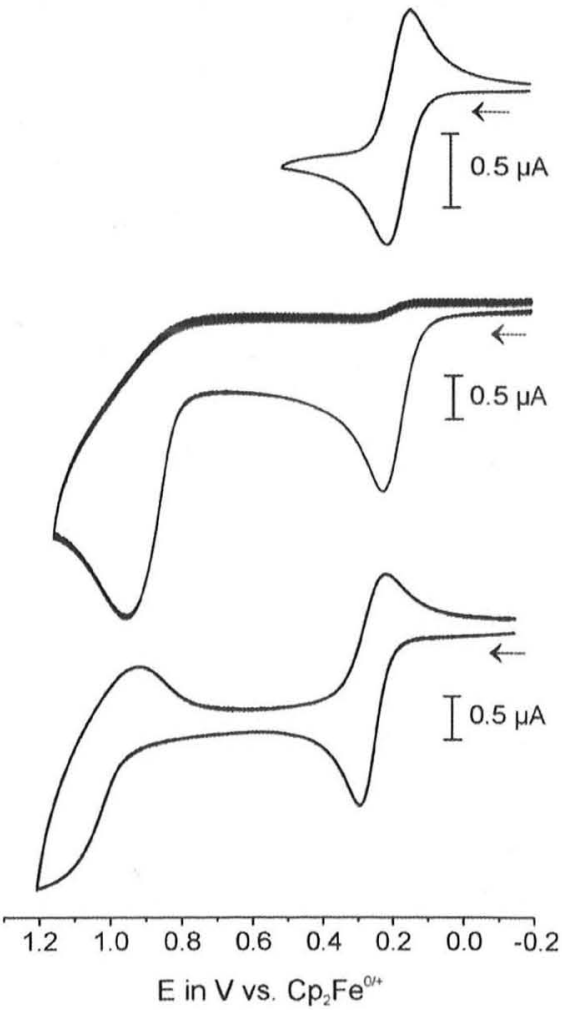

Fig. 8. Voltammograms of 4 in $\mathrm{CH}_{2} \mathrm{Cl}_{2} / \mathrm{NBu}_{4} \mathrm{PF}_{6}(0.1 \mathrm{M})$ at $v=0.1 \mathrm{~V} / \mathrm{s}$ at $195 \mathrm{~K}$ (lower curve), at $v=0.1 \mathrm{~V} / \mathrm{s}$ at RT (middle) and at $v=0.05 \mathrm{~V} / \mathrm{s}$ at RT (top).

remains, however, unclear (see Figs. 7 and 8). A comparison of the half-wave potentials in Table 3 shows that both 2-brominated heterocycles behave as net electron acceptors towards 2,5-dime- 
thylazaferrocene, the 2-bromopyridin-6-yl expectedly more so than the 2-bromomothiophen-5-yl.

For different phosphaferrocenes each substitution of a $\mathrm{CH}$ group by a phosphorus atom results in an average anodic shift of $E_{1 / 2}$ of $196 \mathrm{mV}$ [36]. Similar data sets on azaferrocenes are less extensive. An estimate of the effect of $\mathrm{CH}$ substitution by $\mathrm{N}$ is based on a comparison of 1 '-styryl-2,5-dimethylazaferrocene $\left(E_{1 / 2}=0.18 \mathrm{~V}\right)$ with styrylferrocene $\left(E_{1 / 2}=0.025 \mathrm{~V}\right)[20]$ and of 2,5-dimethylazaferrocene $5(0.17 \mathrm{~V})[40]$ with $1,1^{\prime}$-dimethylferrocene $(-0.10 \mathrm{~V})$ [39]. Under the provision that each methyl group on the azaferrocene induces the same $50 \mathrm{mV}$ cathodic shift of the $E_{1 / 2}$ as in ferrocenes [35] and that this shift is independent of the site of attachment, substitution of $\mathrm{Cp}$ by pyrrolyl induces an anodic shift of $\mathrm{ca}$. $260 \mathrm{mV}$. The effect of nitrogen incorporation is then about $65 \mathrm{mV}$ larger than that induced by a $\mathrm{P}$ atom, which is in accord with the larger calculated charge shift in azaferrocenes compared to their phosphorus analogs [38].

\section{Conclusions}

Palladium catalysed cross-coupling reactions of 2,5-dimethylazaferrocenezinc chloride with selected bromoarenes are described. This novel synthetic strategy complements the available array of methods for azaferrocene functionalization. Our voltammetric results on complexes 3-5 indicate that, under appropriate conditions, 2,5-dimethylazaferrocene and its derivatives are electrochemically well-behaved such that their corresponding radical cations may be amenable to spectroscopic studies. The 1'-heteroaryl-2,5-azaferrocenes described herein are potentially interesting building blocks for the design of new $\pi$-conjugated conductive materials or as electroactive ligands for redox-regulated catalysis [41]. Work directed to further functionalization of the $\mathrm{C}-\mathrm{Br}$ bonds of $\mathbf{3}$ and $\mathbf{4}$ and to the spectroscopic characterization of azaferrocenium radical cations is underway in our laboratories.

\section{Experimental}

\subsection{General remarks}

All preparations were carried out using standard Schlenk techniques. Chromatographic separations were carried out using silica gel 60 (Merck, 230-400 mesh ASTM). Tetrahydrofuran was distilled over sodium benzophenone ketyl. Other solvents were of reagent grade and were used without prior purification. 2,5-Dimethylazaferrocene was prepared according to the literature procedure [42]. All other chemicals were purchased from the Aldrich Chemical Co. The NMR spectra were recorded on a Bruker AV300 spectrometer. Chemical shifts are reported in $\delta(\mathrm{ppm})$ using residual $\mathrm{CHCl}_{3}\left({ }^{1} \mathrm{H}\right.$ $\delta 7.26 \mathrm{ppm})$ and $\mathrm{CDHCl}_{2}\left({ }^{1} \mathrm{H} \delta 5.32 \mathrm{ppm}\right)$ as the reference. Mass spectra were recorded using EI methods on a Finnigan MAT 710A spectrometer. Microanalyses were determined by Analytical Services of the University of Regensburg.

Electrochemical work was performed on a BAS CV50 potentiostat in a home-built vacuum tight one-compartment cell using Pt or glassy carbon disk electrodes from BAS as the working electrode, a platinum spiral as the counter electrode and a silver spiral as a pseudo-reference electrode. Each of the spiral-shaped electrodes was welded to Vycon wire and sealed into a glass tube. Counter and reference electrodes are introduced into the cell by appropriate fittings in the side-wall and sealed via a Quickfit screw. $\mathrm{CH}_{2} \mathrm{Cl}_{2}$ for electrochemical use was of Burdick \& Jackson brand (Fluka) and was distilled from $\mathrm{CaH}_{2}$, deoxygenated by saturation with argon and briefly stored over molecular sieves. Potential calibration was performed by adding ferrocene or decamethylferrocene $\left(E_{1 / 2}=\right.$ $-0.545 \mathrm{~V}$ versus $\mathrm{Cp}_{2} \mathrm{Fe}^{\mathrm{O/+}}$ ) as an internal standard to the analyte solution. The amount of the reference system was adjusted until its peak currents were comparable to those of the analyte. Potentials are given against the ferrocene/ferrocenium couple.

\subsubsection{Synthesis of 1'-(2-bromothiophen-5-yl)-2,5-} dimethylazaferrocene (3)

Sec-BuLi (1.4 M in cyclohexane, $1.2 \mathrm{ml}, 1.7 \mathrm{mmol}$ ) was added to an argon-saturated THF $(12 \mathrm{ml})$ solution of 2,5-dimethylazaferrocene $(230 \mathrm{mg}, 1.07 \mathrm{mmol}$ ) and TMEDA (95 $\mu \mathrm{l}, 0.06 \mathrm{mmol}$ ) at $-78^{\circ} \mathrm{C}$. After the mixture was stirred for $1.5 \mathrm{~h}$ at $-78^{\circ} \mathrm{C}, \mathrm{ZnCl}_{2}$ (222 $\mathrm{mg}, 1.63 \mathrm{mmol}$ ) was added. The reaction mixture was warmed to room temperature and stirred for $1.5 \mathrm{~h}$. Upon warming the coloration of the mixture changed from brown-red to orange. Then a suspension of $\mathrm{PdCl}_{2}\left(\mathrm{PPh}_{3}\right)_{2}(42 \mathrm{mg}, 0.06 \mathrm{mmol})$ in THF $(2 \mathrm{ml})$ and a solution of 2,5-dibromothiophene $(271 \mathrm{mg}, 1.12 \mathrm{mmol}$ ) in THF $(2 \mathrm{ml})$ were added to the reaction mixture and stirring was continued at room temperature for $1.5 \mathrm{~h}$. The reaction mixture was poured into water. After workup, compound $\mathbf{3}$ was purified by column chromatography on silica gel by eluting with ethyl acetate and crystallized from $n$-hexane. Yield $183 \mathrm{mg}(46 \%)$.

${ }^{1} \mathrm{H}$ NMR $\left(300 \mathrm{MHz}, \mathrm{CDCl}_{3}\right): \delta 6.90\left(\mathrm{~d}, 1 \mathrm{H},{ }^{3} \mathrm{JHH}_{\mathrm{HH}}=3.8 \mathrm{~Hz}, \mathrm{H}\right.$ thiophene), $6.82\left(\mathrm{~d}, 1 \mathrm{H},{ }^{3} \mathrm{~J}_{\mathrm{HH}}=3.8 \mathrm{~Hz}, \mathrm{H}\right.$ thiophene), $4.43(\mathrm{t}, 2 \mathrm{H}$, $\left.{ }^{3} J_{\mathrm{HH}}=1.6 \mathrm{~Hz}, \mathrm{Cp}\right), 4.30\left(\mathrm{t}, 2 \mathrm{H},{ }^{3} \mathrm{JHH}_{\mathrm{HH}}=1.6 \mathrm{~Hz}, \mathrm{Cp}\right), 4.27(\mathrm{~s}, 2 \mathrm{H}, \beta-\mathrm{pyrr}-$ olyl), 2.11 (s, $6 \mathrm{H}, 2 \times \mathrm{CH}_{3}$ ). MS (EI, $70 \mathrm{eV}$ ): $\mathrm{m} / \mathrm{z} 374.9\left(\mathrm{M}^{+}\right), 281.9$ $\left(\mathrm{M}^{+}-\mathrm{C}_{6} \mathrm{H}_{8} \mathrm{~N}\right)$. Anal. Calc. for $\mathrm{C}_{15} \mathrm{H}_{14} \mathrm{NSBrFe}$ C, 48.01; $\mathrm{H}, 3.76 ; \mathrm{N}$, $3.73 ;$ S, 8.53. Found: $C, 48.50 ; H, 3.76 ; N, 3.55 ; S, 8.80 \%$.

\subsubsection{Synthesis of 1'-(2-bromopyridin-6-yl)-2,5-}

dimethylazaferrocene (4)

The synthesis was performed as in Section 4.1 .1 but with 2,6dibromopyridine (260 mg, $1.10 \mathrm{mmol}$ ). Yield: $170 \mathrm{mg}(43 \%)$.

${ }^{1} \mathrm{H}$ NMR $\left(300 \mathrm{MHz}, \mathrm{CD}_{2} \mathrm{Cl}_{2}\right): \delta 7.49\left(\mathrm{t}, 1 \mathrm{H},{ }^{3} \mathrm{JHH}_{\mathrm{HH}}=7.6 \mathrm{~Hz}, \mathrm{H}\right.$ pyridine), $7.38\left(\mathrm{~d}, 1 \mathrm{H},{ }^{3} \mathrm{JH}_{\mathrm{HH}}=7.6 \mathrm{~Hz}, \mathrm{H}\right.$ pyridine $), 7.30(\mathrm{~d}, 1 \mathrm{H}$, ${ }^{3} J_{\mathrm{HH}}=7.6 \mathrm{~Hz}, \mathrm{H}$ pyridine), $4.83\left(\mathrm{t}, 2 \mathrm{H},{ }^{3} \mathrm{JHH}_{\mathrm{HH}}=1.9 \mathrm{~Hz}, \mathrm{Cp}\right), 4.41(\mathrm{t}$, $\left.2 \mathrm{H},{ }^{3} \mathrm{~J}_{\mathrm{HH}}=1.9 \mathrm{~Hz}, \mathrm{Cp}\right), 4.25(\mathrm{~s}, 2 \mathrm{H}, \beta$-pyrrolyl), $1.96(\mathrm{~s}, 6 \mathrm{H}, 2 \times$ $\left.\mathrm{CH}_{3}\right) .{ }^{1} \mathrm{H}$ NMR $\left(300 \mathrm{MHz}, \mathrm{CDCl}_{3}\right): \delta 7.45\left(\mathrm{t}, 1 \mathrm{H},{ }^{3} J_{\mathrm{HH}}=.6 \mathrm{~Hz}, \mathrm{H}\right.$ pyridine), 7.35 (d, $1 \mathrm{H},{ }^{3} J_{\mathrm{HH}}=7.6 \mathrm{~Hz}, \mathrm{H}$ pyridine), 7.29 (d, $1 \mathrm{H}$ shielded by solvent signal, $\mathrm{H}$ pyridine), $4.87(\mathrm{~s}, 2 \mathrm{H}, \mathrm{Cp}), 4.41(\mathrm{~s}, 2 \mathrm{H}, \mathrm{Cp})$, 4.25 (s, 2H, $\beta$-pyrrolyl), 2.01 (s, $6 \mathrm{H}, 2 \times \mathrm{CH}_{3}$ ). MS (EI, $70 \mathrm{eV}$ ): $\mathrm{m} / \mathrm{z}$ $369.8\left(\mathrm{M}^{+}\right)$, $290.0\left(\mathrm{M}^{+}-\mathrm{HBr}\right)$. Anal. Calc. for $\mathrm{C}_{16} \mathrm{H}_{15} \mathrm{~N}_{2} \mathrm{BrFe}: \mathrm{C}$, $51.90 ; \mathrm{H}, 4.09 ; \mathrm{N}, 7.57$. Found: C, 51.67; H, 4.16; N, 7.47\%.

\section{Crystal structure determination}

Diffraction data for crystals of compounds $\mathbf{3}$ and $\mathbf{4}$ were collected with an Oxford Diffraction Gemini Ultra CCD diffractometer [43] with multilayer optics and $\mathrm{Cu} K \alpha$ radiation $(\lambda=1.5418 \AA)$. The structures were solved by direct methods (sIR-97) [44] and refined by full-matrix least-squares on $F^{2}$ (SHELxL-97) [45]. $\mathrm{H}$ atoms were calculated geometrically and a riding model was applied during the refinement process. Packing diagrams were generated with the MERCURY program [46].

\section{Supplementary material}

CCDC 675450 and 675451 contain the supplementary crystallographic data for this paper. These data can be obtained free of charge from The Cambridge Crystallographic Data Centre via www.ccdc.cam.ac.uk/data_request/cif.

\section{Acknowledgement}

K.K. is grateful to the Alexander von Humboldt-Stiftung for a research fellowship at the group of Prof. Dr. R.F. Winter, University of Regensburg. 


\section{References}

[1] Y. Zhu, M.O. Wolf, Chem. Mater. 11 (1999) 2995.

[2] M.O. Wolf, Y. Zhu, Adv. Mater. 12 (2000) 599.

3] C. Loubser, C. Imrie, J. Chem. Soc., Perkin Trans. 2 (1997) 399.

14] C. Imrie, C Loubser J. Chem Chem Commun (1994) 2159.

[5] Yu. G. Galyametdinov, O.N. Kadkin, J.V. Ovchinnikov, Izv. Akad. Nauk. SSSR, Ser. Kim. (1990) 2462

[6] I.R. Butler, J.L. Roustan, Can. J. Chem. 68 (1990) 2212.

[7] I.R. Butler, Organometallics 11 (1992) 74.

[8] P.D. Beer, J.P. Danks, M.G.B. Drew, J.F. McAleer, J. Organomet. Chem. 476 (1994) 63.

[9] C.J. Isaac, C. Price, B.R. Horrocks, A. Houlton, M.R.J. Elsegood, W. Clegg, J. Organomet. Chem. $598(2000) 248$.

[10] P. Edinç, A.M. Önal, S. Özkar, J. Organomet. Chem. 692 (2007) 1983.

[11] B. Neumann, U. Siemeling, H.-G. Stammler, U. Vorfeld, J.G.P. Delis, P.W.N.M. van Leeuwen, K. Vrieze, J. Fraanje, K. Goubitz, F.F. de Biani, P. Zanello, J. Chem. Soc., Dalton. Trans. (1997) 4705.

[12] K. Tani, T. Mihana, T. Yamagata, T. Saito, Chem. Lett. (1991) 2047.

[13] O.N. Chupakhin, I.A. Utepova, I.S. Kovalev, V.L. Rusinov, Z.A. Starikova, Eur. J. Inorg. Chem. (2007) 857.

[14] J. Rajput, A.T. Hutton, J.R. Moss, H. Su, C. Imrie, J. Organomet. Chem. 691 (2006) 4573

[15] C.-M. Liu, B.-H. Chen, W.-Y. Liu, X.-L. Wu, Y.-X. Ma, J. Organomet. Chem. 598 (2000) 348.

[16] K. Kowalski, J. Zakrzewski, J. Organomet. Chem. 689 (2004) 1046.

[17] K. Kowalski, J. Zakrzewski, L. Jerzykiewicz, J. Organomet. Chem. 690 (2005) 764.

[18] K. Kowalski, J. Zakızewski, L. Jerzykiewicz, J. Organomet. Chem. 690 (2005) 1474

[19] K. Kowalski, J. Zakrzewski, N.J. Long, N. Suwaki, D.J. Mann, A.J.P. White, Dalton. Trans. (2006) 571

[20] K. Kowalski, J. Zakrzewski, M. Palusiak, S. Domagała, New J. Chem. 30 (2006) 901.

[21] K. Kowalski, J. Zakrzewski, N.J. Long, S. Domagała, A.J.P. White, J. Organomet. Chem. 691 (2006) 3902.

[22] K. Kowalski, S. Domagała, J. Organomet. Chem. 692 (2007) 3100.

[23] P.D. Byrne, P. Müller, T. Swager, Langmuir. 22 (2006) 10596.

[24] C. Imrie, C. Loubser, P. Engelbrecht, C.W. McCleland, J. Chem. Soc., Perkin Trans. 1 (1999) 2513
[25] M. Tsukazaki, M. Tinkl, A. Roglans, B.J. Chapell, N.J. Taylor, V. Snieckus, J. Am. Chem. Soc. 118 (1996) 685.

26] R. Knapp, M. Rehahn, J. Organomet. Chem. 452 (1993) 235.

[27] C.-M. Liu, B.-H. Chen, W.-Y. Liu, X.-L. Wu, Y.-X. Ma, J. Organomet. Chem. 598 (2000) 348.

[28] A.V. Tsvetkov, G.V. Latyshev, N.V. Lukashev, I.P. Beletskaya, Tetrahedron Lett. 41 (2000) 3987.

[29] V. Mamane, I. Ledoux-Rak, S. Deveau, J. Zyss, O. Riant, Synthesis (2003) 455

[30] V. Mamane, O. Riant, Tetrahedron 57 (2001) 2555.

[31] V. Mamane, Y. Fort, J. Org. Chem. 70 (2005) 8220.

[32] M. Iyoda, T. Kondo, T. Okabe, H. Matsuyama, S. Sasaki, Y. Kuwatani, Chem. Lett. (1997) 35.

[33] O.N. Chupakhin, I.A. Utepova, I.S. Kovalev, V.L. Rusinov, Z.A. Starykova, Eur. J. Inorg. Chem. (2007) 857.

[34] P. Audebert, F. Miomandre, J. Zakrzewski, J. Electroanal. Chem. 530 (2002) 63.

[35] P. Lemoine, M. Gross, P. Braunstein, F. Mathey, B. Deschamps, J.H. Nelson, Organometallics 3 (1984) 1303.

[36] R.F. Winter, W.E. Geiger, Organometallics 18 (1999) 1827.

[37] M.G. Peterleitner, L.I. Denisovich, N.I. Pyshnograeva, D.N. Kratsov, Metallorg. Khim. 3 (1990) 581

38] G. Frison, F. Mathey, A. Sevin, J. Phys. Chem. A 106 (2002) 5653.

[39] 1,3-Dimethylferrocene, which corresponds more closely to 2,5dimethylazaferrocene has occasionally been reported but, to the best of our knowledge, no mention of its half-wave potential has been made

[40] The $E_{1 / 2}$ of 2,5-dimethylazaferrocene has been given under less ideal conditions as $240 \mathrm{mV}$ (see Ref. [21]), which is somewhat higher than our value of $170 \mathrm{mV}$.

[41] C.K.A. Gregson, V.C. Gibson, N.J. Long, E.L. Marshall, P.J. Oxford, A.J.P. White, J. Am. Chem. Soc. 128 (2006) 7410.

[42] J. Zakrzewski, Inorg. Chim. Acta 278 (1998) 101

[43] CRYSALIS CCD, Oxford Diffraction Ltd., Version 1.171.32.5 (release 08-05-2007 CrysAlis171.NET).

[44] A. Altomare, M.C. Burla, M. Camalli, G.L. Cascarano, C. Giacovazzo, A. Guagliardi, A.G.G. Moliterni, G. Polidori, R. Spagna, J. Appl. Cryst. 32 (1999) 115.

[45] G.M. Sheldrick, SHELxL-97. Program for Crystal Structure Refinement, University of Göttingen, Germany, 1997.

[46] MERCURY Program for Crystal Structure Visualisation and Exploration, Version 1.4.2, CCDC, Cambridge, UK. 